\title{
Quality of institutions and the BRIC countries agro-food exports
}

\begin{abstract}
Purpose - This paper investigates the impacts of institutional quality in exporting and importing countries on agro-food exports from the world's leading emerging economies: Brazil, the Russian Federation, India, and China (BRIC countries).

Design/methodology/approach - Measuring is based on using the gravity trade model and econometric panel data analysis for the period 1998-2009.

Findings - Agro-food export from the BRIC countries has increased particularly by Brazil and China. The Russian Federation has experienced stagnating and volatile patterns. Brazil and India have strengthened market shares on the existing importing markets, while the Russian Federation has experienced severe deterioration. Export of existing products is more important than of new products. Agro-food export is positively associated with institutional quality in exporting and importing countries, gross domestic product and population sizes in importing countries, but negatively with distance.
\end{abstract}

Research limitations/implications - Among institutional quality variables, the focus is on indices of legal structure and security of property rights and freedom to trade internationally in agro-food importing countries and the BRIC exporting countries.

Practical implications - Different institutions and their quality affect agro-food exports differently. The impact of institutions is not uniform across product groups.

Originality/value - This paper adds the impacts of institutional quality on agro-food exports. Except for processed products for final household consumption, agro-food export from the BRIC countries is positively associated with freedom to trade internationally and quality of legal system as institutional quality in exporting and importing countries.

Keywords: Agro-food export, Gravity model, Institutional quality, Panel data analysis, Emerging market economies 
Paper type Research paper

JEL codes: F14, Q17, C23, O57

\section{Introduction}

During the last decades agro-food export growth has been shaped by different supply-side and demand-side factors (e.g. Bojnec and Fertő, 2008, 2009, 2012; Chen, 2011; Li, 2012). The special focus is on investigation at the impacts of institutional quality $(I Q)$ in exporting and importing countries on agro-food export of the world's leading emerging economies: Brazil, the Russian Federation, India, and China (BRIC). The paper employs gravity model using panel data. The novelty and empirical contribution of the paper are threefold.

First, the comparative analysis of intensive and extensive margins in the BRIC agro-food export by the existing and new importing countries and by the Broad Economic Categories (BECs). The previous studies by McDonald et al. (2008) reported the dramatic expansion of export by India and China by productivity growth. This rapid export growth has been achieved by export specialization towards the expansion of existing competitive products (the intensive margin) and by export restructuring towards the expansion of the number of export varieties (the extensive margin). Bingzhan (2011) found that China's export growth is mainly driven by quantity growth, and less by extensively margin- and quality-driven growth. Although there is an increasing literature on the BRIC countries trade, except for Haq and Meilke (2010), the research on comparative analysis of the BRIC agro-food trade patterns and their determinants is limited.

This paper distinguishes between intensive and extensive margins in the rapid agro-food export growth by the BRIC countries, particularly from China (e.g. Chen et al., 2008; Schott, 2008). Traditional specialization tends to be favorable for the expansion of existing products (the intensive margin). Export-oriented growth across countries tends to combine both the 
expansion of existing products (the intensive margin) and particularly an expansion of the number of export varieties (the extensive margin) (Feenstra, 1994; Hummels and Klenow, 2005).

Second, in addition to gravity model explanatory variables, the particular focus is on investigation at the impacts of $I Q$ in exporting and importing countries on the BRIC countries agro-food export. The recent economic crisis and trade facilitation reform shed light on the importance of hard and soft infrastructure and institutions explaining trading and export flows. Empirical papers find evidence supporting a hypothesis that $I Q$ is an important determinant of sectoral export performances (e.g. Blanchard and Kremer, 1997; Berkowitz et al., 2006; Levchenko, 2007; Ranjan and Lee, 2007; Nunn, 2007; Méon and Sekkat, 2008; Martincus and Gallo, 2009; Hansen et al., 2011). A better $I Q$ can ensure a better contracting environment and their enforcement, and greater transparency with their direct and indirect effects for countries' export patterns.

Differently from most previous studies, we hypothesize that different institutions and their quality also affect agro-food exports differently. The impact of institutions is not uniform across product groups (Levchenko, 2007; Méon and Sekkat, 2008). The specificity of agrofood products in comparison to other sectors is that their trade requires the specific compliance with specific phytosanitary, veterinary, food quality and health standards and practices with specific institutions and trade requirements that might play an important role for agro-food exports (Chen et al., 2008; Engler et al., 2012; Zheng et al., 2013). It is assumed that agro-food products are different, in that food products are more complex differentiated goods than primary agricultural produce. Agriculture and the food sector differ from each other by degree of vertical level of production. Agriculture is more subject to specific government support measures, while food products are in addition more subject to public and private food standards (Jongwanich, 2009). 
It is also expected that better $I Q$ will raise exports by lowering international transactional costs for more complex food products. The reduction of export subsidies and improved market access by the reduction of import tariffs and lower agro-food trade barriers might also contribute to exports. The set standards and rules of the game improve trust and encourage food exports.

Due to a product-specific $I Q$, different types of institutions may differently affect agrofood exports by products. Among IQ variables, the focus is on CATO's indices on legal structure and security of property rights and freedom to trade internationally (Cato EFW, 2011) in the agro-food exporting BRIC countries and in their importing countries. CATO's index for legal structure and security of property rights includes $I Q$ for judicial independence, impartial courts, protection of property rights and integrity of the legal system. CATO's index for international freedom of trade measures the degree to which general business conditions in the country support both internationalization and the export and import activities of companies. The components in the index for international freedom of trade are designed to measure a wide variety of restraints that affect international exchange such as tariffs, quotas, hidden administrative restraints and exchange rate and capital controls. Their role on the BRIC countries agro-food export might be different by BECs as determinants of product specialization patterns (Kehoe and Ruhl, 2002; Broda and Weinstein, 2006; Schott, 2008).

Finally, the empirical findings on the BRIC countries agro-food export have important implications for global agro-food trade and markets with welfare gains for economic developments. The higher quality of institutions in exporting and importing countries has encouraged the BRIC agro-food export owing from more transparent legal system and more liberalized trade for bulk raw and semi-processed agro-food products. At the same time these processes have induced a greater competition for high quality agro-food produce as 
challenging issues for restructuring and improvement changes in competition with more advanced and globally competitive producers (Jongwanich, 2009).

In the next two sections 2 and 3 are presented the BRIC countries export developments focusing on intensive and extensive margins in the BRIC agro-food exports. Additional section 4 sets out the methodology focusing on the role of $I Q$ in exporting and importing countries on agro-food export performance in the BRIC countries, and describes the data used. The followed section 5 presents and explains the econometric results. The section 6 derives findings and economic development and policy implications. The final section 7 concludes and provides directions for future research.

\section{The BRIC countries agro-food export developments}

This section presents analysis of BRIC agro-food export flows focusing on the difference among BRIC countries in terms of export growth, composition of exports and the role of new partners in export growth.

Figure 1 confirms that agro-food exports from the BRIC countries have increased. The increasing patterns of agro-food exports are seen for each of the BRIC countries, particularly in an absolute amount for Brazil and China. During 2009, except for the Russian Federation, the other three BRIC countries have experienced stagnating or even declining agro-food export developments.

However, agro-food export developments in the BRIC countries have been rather volatile over time by annual oscillations. The most recent decline in the BRIC agro-food export might be a consequence of two effects: an increase in international agro-food competition from developed and other emerging market economies on supply-side and demand-side effect determined by economic recession caused by the output decline (Bojnec and Fertő, 2012; Zhu 
et al., 2013; Wen et al., 2013). Therefore, the most recent economic recession has also caused the deterioration in agro-food export from the BRIC countries.

Insert Figure 1.

The composition of agro-food export varies considerably among the BRIC countries and by BECs (Table 1). For Brazil, BEC112 - primary products mainly for household consumption - is the least important in the composition of agro-food export. The most important is BEC122 - processed food and products intended for final consumption in households followed by BEC111 - primary products (food and beverages) mainly for industry and BEC121 - processed products mainly for industry. In addition, standard deviation indicates oscillations by individual years.

For China BEC122 is far the most important in the composition of agro-food export followed by BEC112. BEC111 takes a lower percentage, while BEC121 is less important.

The composition of Indian agro-food export is also rather volatile over time. BEC112 and BEC122 are the most important in the composition of agro-food export, while BEC121 has the lowest importance.

The Russian Federation has experienced not only the instabilities in patterns of agro-food export developments, but also in its composition. In a spite of these instabilities, BEC111 and BEC122 have achieved the greatest share in agro-food export composition, but this varies considerably by years.

Insert Table 1.

\section{Intensive and extensive margins in the BRIC agro-food exports}




\subsection{Descriptive analysis}

The BRIC countries agro-food export developments are investigated by BECs and by importing countries. It is expected that BRIC countries agro-food export growth tends to combine both the intensive margin with export in primary commodities and the extensive margin with export varieties in processed products in new growing importing countries (Feenstra, 1994; Hummels and Klenow, 2005). In addition, it is expected that the BRIC countries agro-food exports in processed products and in new importing countries have increased faster than in primary products and the existing importing countries.

The share in the number of the BRIC stable existing agro-food importing countries, which have imported from the BRIC countries every year, indicates the intensity of the intensive margin in agro-food exports from the BRIC countries to the existing importing countries. As can be seen from Figure 2 this varies by the BRIC countries and by the BECs. The share of the existing importing countries has declined over the analyzed period. This deterioration in the intensity of the BRIC existing agro-food importing countries suggests the presence of the extensive margin in the BRIC agro-food exports with a shift of agro-food exports towards new emerging importing countries.

Among the BEC agro-food categories the share of the intensity of the BRIC existing agrofood importing countries is the highest for BEC112 and BEC122.

Insert Figure 2.

Figure 3 compares the share in the value of the BRIC existing importing countries in agrofood exports with trading every year by the BEC agro-food commodity groups between the years 1998 and 2009. There are differentials in performance between the BRIC countries. Except for BEC112, Brazil and India have increased the intensive margin in agro-food export 
share. China has deteriorated its intensive margin share for BEC121. Russia explores a great volatility: rapid drop for BEC111 and BEC121, but keeping similar share for BEC112 and has experienced an increase for BEC122.

Insert Figure 3.

Insert Figure 4.

The importance of the extensive margin by an expansion in the number of new importing countries and the number of new agro-food export varieties has increased a slightly. As can be seen from Figure 4, the number of importing countries by the BEC agro-food commodity groups has increased by the BRIC countries.

The most important importing countries for agro-food exports from Brazil are developed and developing countries all over the world. In 2009, among the top five importing countries for agro-food exports from Brazil by the BECs are as follows: China, Germany, the Netherlands, Spain and the United States of America (USA) (BEC111); the USA, the Netherlands, the United Kingdom (UK), Germany and Spain (BEC112); India, the Russian Federation, Bangladesh, China and Algeria (BEC121); the Russian Federation, the Netherlands, China, Hong Kong SAR, Saudi Arabia and Japan (BEC122). Some changes among the top five Brazilian agro-food importing countries have been over time. Among the most recent important importing countries are also some developing countries, particularly other three BRIC countries.

The most important importing countries for agro-food exports from China are more concentrated on the Asian region. In 2009, the top five importing countries for agro-food exports from China by the BECs are as follows: China, Hong Kong SAR, Republic of Korea, Japan, Germany and Vietnam (BEC111); Japan, Republic of Korea, the USA, Malaysia and 
China, Hong Kong SAR (BEC112); Republic of Korea, China, Hong Kong SAR, Japan, the USA and Vietnam (BEC121); Japan, the USA, China, Hong Kong SAR, Republic of Korea and Germany (BEC122). The findings for China's agro-food importing countries suggest greater stability among the top five importing countries from the region and developed countries from the rest of the world.

The most important importing countries for agro-food exports from India are more concentrated on the proximate countries in the India's region and on some developed countries in the rest of the word. In 2009, the top five importing countries for agro-food exports from India by the BECs are as follows: Indonesia, Italy, the USA, Malaysia and Philippines (BEC111); the USA, United Arab Emirates, Bangladesh, Japan and the UK (BEC112); : the USA, Saudi Arabia, United Arab Emirates, Bangladesh and Sri Lanka (BEC121); United Arab Emirates, Saudi Arabia, Iran, Vietnam and Kuwait (BEC122). These findings for India's agro-food importing countries also suggest greater stability among the top five importing countries from the India's region, then from oil reach Arab countries and developed countries from the rest of the world.

Finally, the most important importing countries for agro-food exports from the Russian Federation are developing countries in the region, particularly from the former Soviet Union Republics, some other developing countries in the Middle East and some developed countries in the world. In 2009, among the top five importing countries for agro-food exports from the Russian Federation by the BECs are as follows: Turkey, Saudi Arabia, Syria, Azerbaijan and Jordan (BEC111); Republic of Korea, Kazakhstan, Japan, Ukraine and China (BEC112); Turkey, Italy, Afghanistan, Kazakhstan and Egypt (BEC121); Kazakhstan, China, Republic of Korea, Ukraine and Azerbaijan (BEC122). The findings for the Russian Federation agro-food importing countries suggest some changes over time among the top five importing countries. 
The countries from the Soviet Union Republics have still remained important market destinations for the Russian Federation's agro-food exports.

To sum up, these descriptive structures and patterns in the BRIC agro-food export developments suggest two interesting results. First, the number of stable existing importing countries declined to the end of the analyzed period and the number of new importing countries has increased a slightly. Second, the share of stable existing importing countries in value of the BRIC agro-food exports exceeded $90 \%$ for majority of observations, except for the Russian Federation in some cases. These results imply that the source of agro-food export growth from the BRIC countries is the intensive margin by the increase of exports to stable importing countries' markets. This finding for China is also consistent to Bingzhan (2011) that China's export growth is mainly driven by quantity-driven growth for different partners and different industries.

\subsection{Equality tests}

We also test whether the BEC agro-food export growth rates are different between existing and new importing countries by mean comparisons using t-tests. Our results suggest that exports to new importing countries increased significantly faster than to the existing importing countries except for BEC122 (Table 2).

\section{Insert Table 2.}

Finally, we investigate whether the BECs export growth is faster for processed products in new importing countries using mean equality t-tests between BECs in existing and new importing countries. Although export growth rates are usually higher in new importing countries for processed products than primary and semi-processed product groups in existing importing countries (Table 2), t-tests only partly confirm this observation. Surprisingly, despite of large differences in mean export growth rates between BECs in new and existing 
importing countries, pair-wise comparisons show that these differences are significant only between BEC121 and BEC111/BEC112 (Table 3).

Insert Table 3.

\section{Methodology on gravity model and data}

\subsection{Methodology}

We aim to investigate determinants of the BRIC agro-food export developments using gravity trade model and advance econometric panel data analysis. The baseline econometric model explanation starts from traditional gravity theory, which points that bilateral trade is positively associated with their national sizes (incomes and/or population) and negatively associated with their geographical distance (e.g. Anderson, 1979; Frankel and Rose, 2002; Anderson and van Wincoop, 2003; Bojnec and Fertő, 2010; Wen et al., 2013). The increases in national incomes and/or population generate greater demands, and the closest partner's country location lowers transportation costs. Therefore, we employ standard gravity model variables including market size measured by gross domestic product $(G D P)$ and size of population $(P O P)$ of BRIC exporting countries and different importing countries, and geographical distance $(D S)$ between the capital cities between the BRIC country and bilateral importing countries as explanatory variables. Therefore, bilateral trade of exporting BRIC $i$ and importing $j$ countries in time $t\left(E X P_{i j, t}\right)$ is positively associated with their countries sizes $(G D P$ and/or $P O P)$ and negatively associated with their geographical $D S$ (e.g. Anderson \& van Wincoop, 2004). We specify the following baseline gravity trade model:

$\ln E X P_{i j t}=\alpha_{0}+\alpha_{\mathrm{t}}+\alpha_{\mathrm{i}}+\alpha_{\mathrm{j}}+\alpha_{1} \ln G D P_{i t}+\alpha_{2} \ln G D P_{j t}+\alpha_{3} \ln P O P_{i t}+\alpha_{4} \ln P O P_{j t}+\alpha_{5} \ln D S_{i j}+\eta_{i j t}$ 
where $G D P$ is gross domestic product for the economic country size, $P O P$ is population for the demographic country size, and $D S$ is distance between the countries' capitals. According to the gravity approach we expect positive sign for $G D P_{j t}$ and $P O P_{j t}$ in importing $j$ countries, but negative sign for $G D P_{i t}$ and $P O P_{i t}$ in exporting BRIC $i$ countries and for $D S_{i j}$ variables. The BRIC countries have experienced rapid economic growth, while among the BRIC countries, the Russian Federation experiences declining $P O P$ developments due to low fertility and outward migration development with aging $P O P$ and the spatial $P O P$ redistribution by its regions. The $D S s$ between the capitals are time-invariant variables. Proximate countries are expected to export relatively more because transport costs are lower.

Our special focus is on the association between the $I Q$ in exporting BRIC $i$ countries and importing $j$ countries, respectively, and the BRIC bilateral agro-food exports. It is expected that better quality of institutions reduces trade costs and enhances bilateral agro-food export growth. The effect of quality of institutions on export specialization can be both direct and indirect. Good institutions are likely to be associated with lower transaction costs to facilitate contracting and long term agreements between companies. Quality of institutions may have an indirect effect on agro-food exports through investments and productivity improvements. The $I Q$ of exporting and importing countries with high norms of behaviors and institutions both formal and informal in doing international agro-food trade businesses, increases compatibility and trust, and reduces adjustment costs and insecurity in agro-food exports. In other words the $I Q$ is an additional factor affecting relative transaction costs as an explanatory factor in bilateral agro-food trade. We extend our baseline model specification with the $I Q$ explanatory variables:

$\ln E X P_{i j t}=\alpha_{0}+\alpha_{\mathrm{t}}+\alpha_{\mathrm{i}}+\alpha_{\mathrm{j}}+\alpha_{1} \ln G D P_{i t}+\alpha_{2} \ln G D P_{j t}+\alpha_{3} \ln P O P_{i t}+\alpha_{4} \ln P O P_{j t}+\alpha_{5} \ln D S_{i j}+$ $\alpha_{6} I Q_{i t}+\alpha_{7} I Q_{j t}+\eta_{i j t}$ 
where $I Q$ describes the institutional quality in exporting BRIC $i$ countries and importing $j$ countries. We expect that agro-food export from BRIC countries is positively associated with the $I Q$ in exporting and importing countries, respectively.

Estimating the gravity trade model and assessing trade patterns on the basis of the empirical results have been subject to several econometric challenges. The most recent literature has addressed issues concerning the correct specification and interpretation of the gravity trade equation in empirical estimation. We concentrate on two methodological issues. First, several researches have argued that standard cross-sectional methods yield biased results because they do not control for heterogeneous trading relationships (e.g. Feenstra 2004; Helpman et al., 2008). Because of this, these researches introduced the fixed effects into the gravity trade equation. The fixed-effect trade models allow for unobserved or misspecified factors that simultaneously explain trade volume between two countries, such as the probability that the countries will be in the same regional integration regime (e.g. Matyas, 1997; Egger, 2002). Although the arguments underlying the use of the fixed effects as a solution to unobserved heterogeneity are roughly the same in the literature, there is little agreement about how to actually specify the fixed effects. Following Cheng and Wall (2005) we apply the fixed effect methods in which country-pair and period dummies are used to reflect the bilateral relationship between trading partners. Second, issues arising from loglinearization of the gravity equation and the heteroscedasticity nature of trade data. This violates the standard assumption of OLS and suggests that the estimator may be biased and inconsistent. More importantly, this kind of heteroskedasticity cannot be dealt with by simply applying a robust covariance matrix estimator, since it affects the parameter estimates in addition to the standard errors. Consequently, the presence of 
heteroskedasticity under the assumption of a multiplicative error term in the original nonlinear gravity model specification requires adoption of a different estimation methodology . To avoid the heteroscedasticity and other estimation issues including zero values, endogeneity and measurement error, Santos Silva and Tenreyro (2006) proposes the use of the Poisson Psuedo-Maximum-Likelihood (PPML) estimator. In addition, Santos Silva and Tenreyro (2011) show that the PPML estimator is generally well behaved, even when the proportion of zeros in the sample is very large. Thus, to deal with heteroscedasticity issues we apply the PPML estimation technique.

\subsection{Data}

We focus on the period 1998-2009, using export data from UN Comtrade database for agro-food products at the three-digit level of the BEC classification Revision 3: BEC111, BEC112, BEC121, and BEC122.

The BRIC exporting $i$ countries' and importing destination $j$ countries' income (GDP) and the number of inhabitants $(P O P)$ in these countries are collected from the World Bank's (2011) World Development Indicator Database. The distance (DS) between the BRIC and importing bilateral countries is obtained from the CEPII database (Mayer and Zignago, 2006).

The variables of particular interest are for the level of subjective institutional quality (IQ). The dataset includes $I Q$ indices produced by the Fraser Institute for Institutions (Gwartney and Lawson, 2005). The $I Q$ indices are obtained from the 'Economic Freedom of the World' (Cato EFW, 2011) database. The EFW IQ indices are based on several sub-indices designed to measure the degree of 'economic freedom' in the five areas: (1) government expenditures, taxes, and enterprises; (2) legal structure and protection of property rights; (3) access to sound money: inflation rate, and possibility to own foreign currency bank accounts; (4) freedom to trade internationally: taxes on international trade, regulatory trade barriers, capital market controls, difference between official exchange rate and black market rate and similar; and (5) regulation of credit, labor, and business. Each of the economic freedom indices ranges from 0 
to 10 reflecting the distribution of the underlying data. Notionally, a low value denotes a bad performance, and a higher value denotes a superior performance of $I Q$.

The $I Q$ indices differ by different sub-indices for the same country and among the countries. Preliminary analysis shows that all aspects of $I Q$ indices are interrelated, thus the indicators of $I Q$ are highly positively correlated. For that reason, we treat them separately in the empirical analysis, including one dimension of the $I Q$ in the regression equation at a time. Using too many $I Q$ indicators simultaneously results in serious problems of multicollinearity. In our regression analysis we report the results using the indices for legal structure and security of property rights and freedom to trade internationally, respectively.

Table 4 presents summary statistics of variables used in the regression analysis. The value of agro-food exports $(E X P)$ differs between the BRIC countries. The size of GDP of the BRIC countries has been smaller than of the importer countries, and vice versa for the POP size. Considerable differences can be seen for the $I Q$ with higher mean values and greater differential between minimum and maximum values for freedom to trade internationally and for legal structure and protection of property rights for importing countries than for the BRIC exporting countries.

\section{Econometric gravity model results}

\subsection{The baseline model specification}

The baseline econometric model specification shows that the BRIC countries agro-food exports $(E X P)$ is positively associated with the size of the country in terms of GDP and POP only for the importing countries for each of the BECs and negatively associated with the $D S$ between the countries (Table 5).

For the BRIC exporting countries the regression coefficients for the GDP and POP sizes are of mixed signs. Except for BEC111, the GDP size in the BRIC exporting countries is 
positively associated with agro-food exports. In addition, the regression coefficients are increasing with the degree of final household consumption being the highest for the BEC122.

The regression coefficients for the $P O P$ size in the BRIC exporting countries indicate the presence of substitution effect: the BRIC countries POP growth reduces their agro-food exports for BEC111 and BEC121. On the other hand, POP growth in the BRIC countries does not reduce their exports for BEC112 and BEC122.

The increases in the GDP and $P O P$ sizes in importing countries are crucial determinants for agro-food export increases from the BRIC countries. The absolute size of the regression coefficients for the GDP size is higher for BEC112 and BEC122 than for BEC111 and BEC121. Except for BEC122, the increase in the POP size in the importing countries is more important determinant for agro-food exports from the BRIC countries than the GDP size in importing countries.

Insert Table 5.

Consistently with the theoretical expectation, the BRIC countries agro-food export is negatively associated with the $D S$, but the importance of the $D S$ for agro-food export varies by the BECs. The regression coefficients are the lowest for BEC111 and BEC121 than for BEC122 and BEC112. This implies that primary and processed agro-food products mainly for industry are less sensitive to the $D S$ than primary and processed ones mainly for final household consumption, which seem to be traded in more proximity countries.

\subsection{The role of institutional quality (IQ)}

Table 6 reinforces some previous results for the baseline econometric model variables. The BRIC countries the BEC exports is positively associated with the size of country in terms of $G D P$ and $P O P$ for the importing countries and negatively associated with the $D S$ between the 
countries. On the other hand, the regression coefficients for GDP and $P O P$ sizes in the BRIC exporting countries are mixed by BEC agro-food exports. Their negative signs imply a substitution effect of BRIC domestic demand caused by increases in domestic GDP and POP on agro-food exports.

The increases in the GDP and $P O P$ sizes in importing countries are crucial determinants for agro-food export increases from the BRIC countries. The increases in the POP sizes are even more important determinant than GDP sizes for agro-food exports from the BRIC countries. The high absolute size of the regression coefficients pertaining to the $P O P$ size can be explained by the rapid $P O P$ growth in some of the BRIC countries such as in India creating domestic demands for the reduction of agro-food exports, but also with increases of the $P O P$ size in other agro-food importing countries, including agro-food trade between the BRIC countries, creating import demand from the individual BRIC countries.

Insert Table 6.

We test hypothesis that the BRIC countries agro-food export is positively associated with $I Q$ in exporting and importing countries. However, agro-food products are not homogenous and trade in different BECs is likely to require different institutions and their quality. Therefore, we separately test the impact of the two different $I Q$ variables in exporting and importing countries, respectively, on the BRIC countries agro-food export by the BECs: (1) legal structure and protection of property rights and (2) freedom to trade internationally (Table 6).

The regression coefficients pertaining to the $I Q$ of exporting and importing countries are consistently positive for BEC111, BEC112 and BEC121, but for BEC122 of a negative sign in exporting BRIC countries and mixed in importing countries (negative for legal structure 
and protection of property rights and positive for freedom to trade internationally). Except for the BEC122, better $I Q$ in exporting and importing countries with the relatively better legal system and relatively lower tariffs and other import barriers, this encourages agro-food exports from the BRIC countries to importing countries positively. This finding supports the international aims to make governmental institutions more effective with institutional and policy measures, which are supporting more transparent, freer and less distorting international agro-food trade.

For the BEC122, the regression coefficients pertaining to the IQ of exporting countries are of negative sign. This product category contains higher value-added products. Due to lower $I Q$ in the BRIC exporting countries, their agro-food exports have greater difficulties to comply with higher $I Q$ requirements, particularly in legal structure and protection of property rights in importing countries, and competition from the rest of the world in importing countries. This can explain the negative regression coefficient pertaining to the $I Q$ in exporting BRIC countries and the mixed regression coefficients pertaining to the $I Q$ in importing countries where the regression coefficients pertaining to the freedom to trade internationally in importing countries is of an expected positive sign.

These empirical findings cannot reject fully our hypothesis that agro-food exports require compliance with specific $I Q$ institutions in exporting and importing countries, which can have different effects on different exported agro-food products. Therefore, different $I Q$ determines the BEC agro-food exports differently. This implies that successful agro-food exports require different IQs in different agro-food products. The BRIC countries can easier comply with the $I Q$ in bilateral trade for primary and semi-processed products: the BEC111, BEC112 and BEC121. Difficulties can occur to comply with $I Q$ in bilateral trade for the BEC122 exports, which consists of processed food products for final consumption in households. 


\section{Findings and development implications}

The composition of agro-food exports from the BRIC countries varies largely between the countries, the BECs and over time. The prevalence in the composition of agro-food exports from the BRIC is BEC122. In addition, Brazil and the Russian Federation are important exporters for BEC111, while India and China for BEC112. These export specialization patterns can be results of natural factor endowments in the case of BEC111 and BEC112. In the case of BEC122, this can be also due to developed food processing. Statistical tests cannot reject fully hypothesis on faster agro-food export growth from the BRIC countries in processed products and on markets of new importing countries.

Agro-food export from the BRIC countries is positively associated with the GDP size and $P O P$ size in importing countries as well as with $I Q$ in exporting and importing countries for BEC111, BEC112 and BEC121. It is negatively associated with $D S$. It is also negatively associated with the GDP size and POP size in the BRIC exporting countries for BEC112 and BEC121. The latter can be explained by increasing domestic demand, particularly in India and China. While there is prevalence to agro-food export proximity to importing countries in its regions, agro-food exports from Brazil seems to be rather globally oriented.

Except for the BEC122, the positive impact of the $I Q$ in exporting and importing countries on the BRIC bilateral agro-food exports varies between the BECs. Better $I Q$ in exporting and importing countries fosters the BECs exports, but different institutions and their quality in exporting and importing countries can have different impacts between the BECs exports arising from lowering international trade transactional costs. The dismantling of a persistent inefficient $I Q$ in agro-food trade and agro-food trade liberalization with reduction or abolishing tariff and other importing barriers can vary across the BECs and can differently boost the BECs exports. Therefore, different agro-food exports require different institutions as different $I Q$ affects agro-food exports differently. 
The importance of $I Q$ in the regulatory basis and in implementation practices by lowering international trade transaction costs in exporting and importing countries has contributed to increasing the BRIC agro-food exports. Except for BEC122, the positive association between $I Q$ in exporting and importing countries and the BRIC agro-food exports implies the increasing importance of better $I Q$ in exporting and importing countries as a factor of economic growth and development, particularly for agriculture and the food sector.

The negative association between the BEC122 exports from the BRIC countries and the IQ can be explained by lower $I Q$ in exporting BRIC countries to overcome food safety standards and other barriers to trade, which can be imposed by developed countries that could impede processed food exports from developing countries (Jongwanich, 2009). The potential benefits that could emerge from upgrade $I Q$ should be viewed as a challenge in a reduction in transaction costs in meeting the required standards in global agro-food trade.

\section{Conclusion}

The emerging BRIC market economies are due to the large POP size such as China and India as well as due to increasing the GDP size and trade size one of the most challenging issues for international trade. In this paper we have focused on bilateral agro-food exports from the BRIC countries, namely Brazil, the Russian Federation, India and China. They have become important players in global agro-food markets with welfare gains for economic developments. Their bilateral agro-food exports have increased over time. Particularly Brazil and China have contributed to the rapid increase of agro-food exports. On the other hand the Russian Federation has experienced the most volatile agro-food export developments.

The compliance with $I Q$ requirements in exporting and importing countries has played an important role for the BRIC agro-food exports. Agro-food exports from the BRIC countries have been caused by both intensive and extensive margins. Brazil and India have strengthened 
their intensive margin in agro-food exports by gaining market shares in the existing importing countries, while the Russian Federation has experienced the most severe deterioration.

The quality of institutions in the exporting and importing countries can contribute to increases the BRIC agro-food exports. The impact of $I Q$ in terms of legal structure and security of property rights can contribute to greater transparency and confidence between exporters and importers, while freedom to trade internationally can contribute to trade growth owing from lower or abolished trade barriers.

Among issues for future research are to study some other determinants for agro-food export growth such as the role of factor endowments and factors of comparative advantages (Bojnec and Fertő, 2009; Heguang et al., 2009). A shift from intensive margin to extensive margin with exports of product varieties is likely to require innovation and quality improvements by differently disaggregated products, which can be induced by research and development and investment activities in technology advancements and international marketing in global, but by $I Q$ diversified world.

\section{References}

Anderson, J.E. (1979), "A theoretical foundation of the gravity equation", American Economic Review, Vol. 69 No. 1, pp. 106-16.

Anderson, J.E. and van Wincoop, E. (2003), “Gravity with gravitas: a solution to the border problem", American Economic Review, Vol. 93 No. 1, pp. 170-92.

Anderson, J.E. and von Wincoop, E. (2004), "Trade costs", Journal of Economic Literature, Vol. 42 No. 3, pp. 691-751.

Berkowitz, D., Moenius, J. and Pistor, K. (2006), “Trade, law, and product complexity”, Review of Economics and Statistics, Vol. 88 No. 2, pp. 363-73. 
Bingzhan, S. (2011), "Extensive margin, quantity and price in China's export growth", China Economic Review, Vol. 22 No. 2, pp. 233-43.

Blanchard, O. and Kremer, M. (1997), "Disorganization”, Quarterly Journal of Economics, Vol. 112 No. 4, pp. 1091-1126.

Bojnec, Š. and Fertő, I. (2008), "European enlargement and agro-food trade", Canadian Journal of Agricultural Economics, Vol. 56 No. 4, pp. 563-79.

Bojnec, Š. and Fertő, I. (2009), "Determinants of agro-food trade competition of Central European countries with the European Union", China Economic Review, Vol. 20 No. 2, pp. 327-37.

Bojnec, Š . and Fertő, I. (2010), "Internet and international food industry trade", Industrial Management \& Data Systems, Vol. 110 No. 5, pp. 744-761.

Bojnec, Š. and Fertő, I. (2012), “Does EU enlargement increase agro-food export duration?”, The World Economy, Vol. 35 No. 5, pp. 609-31.

Broda, C. and Weinstein, D.E. (2006), "Globalization and the gains from variety", Quarterly Journal of Economics, Vol. 121 No. 2, pp. 541-85.

Cato EFW (2011), Economic Freedom of the World, Cato Institute, Washington, DC. Data retrieved from http://www.cato.org/pubs/efw/.

Chen, C., Yang, J. and Findlay, C. (2008), "Measuring the effects of food safety standards on China's agricultural exports", Review of World Economics, Vol. 144 No. 1, pp. 83-106.

Cheng I.-H. and Wall, H.J. (2005), "Controlling for heterogeneity in gravity models of trade and integration", Federal Reserve Bank of St. Louis Review, Vol. 87 No. 1, pp. 49-63.

Chen, L. (2011), “The effect of China's RMB exchange rate movement on its agricultural export: A case study of export to Japan”, China Agricultural Economic Review, Vol. 3 No. 1, pp. 26-41. 
Egger, P. (2002), "An econometric view on the estimation of gravity models and the calculation of trade potentials", The World Economy, Vol. 25 No. 2, pp. 297-312.

Engler, A., Nahuelhual, L., Cofré, G. and Barrena, J. (2012), "How far from harmonization are sanitary, phytosanitary and quality-related standards? An exporter's perception approach," Food Policy, Vol. 37 No. 2, pp. 162-70.

Feenstra, R. (1994), "New product varieties and the measurement of international prices", American Economic Review, Vol. 84 No. 1, 157-77.

Feenstra, R. (2004), Advanced International Trade: Theory and Evidence, Princeton University Press, Oxford.

Frankel, J.A. and Rose, A. (2002), “An estimate of the effect of common currencies on trade and income", Quarterly Journal of Economics, Vol. 117 No. 2, pp. 437-66.

Gwartney, J. and Lawson, R. (2005), Economic Freedom of the World: 2005 Annual Report, The Fraser Institute, Vancouver. Data retrieved from http://www.freetheworld.com.

Hansen, J., Tuan, F. and Somwaru, A. (2011), "Do China's agricultural policies matter for world commodity markets?", China Agricultural Economic Review, Vol. 3 No. 1, pp. 625.

Haq, Z. and Meilke, K. (2010), "Do the BRICs and emerging markets differ in their agri-food imports", Journal of Agricultural Economics, Vol. 61 No. 1, pp. 1-14.

Heguang, L., Tada, M. and Dongsheng, S. (2009), "Changing patterns in comparative advantage for agricultural trade in East Asian countries", China Agricultural Economic Review, Vol. 1 No. 2, pp. 227-38.

Helpman, E., Melitz, M. and Rubinstein, Y. (2008), "Estimating trade flows: trading partners and trading volumes", Quarterly Journal of Economics, Vol. 123 No. 2, pp. 441-87.

Hummels, D. and Klenow, P. (2005), “The variety and quality of a nation's exports", American Economic Review, Vol. 95 No. 3, pp. 704-23. 
Jongwanich, J. (2009), “The impact of food safety standards on processed food exports from developing countries", Food Policy, Vol. 34 No. 5, pp. 447-57.Kehoe, T. and Ruhl, K. (2002), How Important is the New Goods Margin in International Trade? Federal Reserve Bank of Minnesota, Minnesota.

Levchenko, A. (2007), "Institutional quality and international trade", Review of Economic Studies, Vol. 74 No. 3, pp. 791-819.

Li, X. (2012), “Technology, factor endowments, and China's agricultural foreign trade: a neoclassical approach", China Agricultural Economic Review, Vol. 4 No. 1, pp. 105-23.

Martincus, C.V. and Gallo, A. (2009), "Institutions and export specialization: just direct effects?", Kyklos, Vol. 62 No. 1, pp. 129-49.

Matyas, L. (1997), "Proper econometric specification of the gravity model", The World Economy, Vol. 20 No. 3, pp. 363-69.

Mayer, T. and Zignago, S. (2006), Notes on CEPII's Distance Measure. Data retrieved from www.cepii.fr/anglaisgraph/bdd/distances.htm.

Méon, P-G. and Sekkat, K. (2008), “Institutional quality and trade: which institutions? Which trade?", Economic Inquiry, Vol. 46 No. 2, pp. 227-40.

McDonald, S., Robinson, S. and Thierfelder, K. (2008), “Asian growth and trade poles: India, China, and East and Southeast Asia", World Development, Vol. 36 No. 2, pp. 210-34.

Nunn, N. (2007), "Relationship-specificity, incomplete contracts, and the pattern of trade", Quarterly Journal of Economics, Vol. 122 No. 2, pp. 569-600.

Ranjan, P. and Lee, J.Y. (2007), "Contract enforcement and the volume of international trade in different types of goods", Economics and Politics, Vol. 19 No. 2, pp. 191-218.

Santos Silva, J. and Tenreyro, S. (2006), "The log of gravity", Review of Economics and Statistics Vol. 88 No. 4, pp. 641-658 
Santos Silva, J. and Tenreyro, S. (2006), "Further simulation evidence on the performance of the Poisson pseudo-maximum likelihood estimator", Economics Letters, Vol. 112. pp. $220-222$

Schott, P.K. (2008), "The relative sophistication of Chinese exports", Economic Policy, Vol. 23 No. 1, pp. 5-49.

UN Comtrade database (2011), United Nations Commodity Trade Statistics Database United Nations, New York. http://comtrade.un.org/.

Wen, S., Zheng, J. and Liu, X. (2013), “An analysis on China's agricultural bilateral trade costs? 1995-2007”, China Agricultural Economic Review, Vol. 5 No. 3, pp. 360-372.

World Bank (2011), World Development Indicators, The World Bank, Washington, DC. Data retrieved from http://data.worldbank.org/indicator.

Zheng, Y., Muth, M. and Brophy, J. (2013). "The impact of food safety third-party certifications on China's food exports to the United States," 2013 Annual Meeting, August 4-6, 2013, Washington, D.C., Agricultural and Applied Economics Association.

Zhu, J., Zhang, S. and Yu, W. (2013), “Agricultural trade and farm employment in China during 1994-2009: Job creation or substitution?", China Agricultural Economic Review, Vol. 5 No. 2, pp. 180-196. 